\title{
Ganoderma Lucidum Induced Acute Pancreatitis in The Elderly
}

\section{Yaşlı Bir Hastada Ganoderma Lucidum Mantarının Yol Açtığı Akut Pankreatit}

Arif Yüksel ${ }^{* 1}$, Emre Gezer ${ }^{1}$, Zeynep Zehra Gümüş ${ }^{2}$ Öze Tuncer ${ }^{3}$

ÖZET

Ganoderma lucidum ( Japoncada'da Reishi, Çince'de Lingzhi) popüler bir tıbbi mantardır ve Çin tıbbında yaklaşık 2.000 yıldır kullanılmaktadır Son 30 yılda, bu mantarlar, modern farmakologlar tarafından incelenmiştir . Pek çok çalışma, G. lucidum'un immün fonksiyonları düzenlediği ve tümör büyümesinin engellenmesinde etkili olduğunu göstermiştir. Bu etkilerin dışında G. lucidum ayrıca hipertansiyon, hiperlipidemi, diyabet, nefrit, astım, arterit, iltihaplı bağırsak hastalıkları ve diğer hastalıkların tedavisinde de kullanılabilir olduğu gösterilmiştir. Bu etkilerin belli mekanizması hala belirsizdir. Bu nedenle, G. lucidum bir terapötik madde olarak tavsiye edilmez. Çoğunlukla, bir bağışıklık arttırıcı ve sağlık için ek gıda olarak kullanılır. Bu olgu sunumunda, farklı klinik bulgularla kliniğimize başvuran akut pankreatitli bir olgu sunulmuştur.

Anahtar kelimeler: Akut pankreatit, ganoderma lucidum

\begin{abstract}
Ganoderma lucidum (Lingzhi in Chinese and Reishi in Japanese) is a popular medicinal mushroom and has been used for about 2.000 years in Chinese medicine. In the last 30 years, this fungi has been investigated by modern pharmacologists. Several studies showed that G. lucidum is effective in modulating immune functions and inhibiting tumor growth. Other than these effects, G. lucidum has also been demonstrated that it can be used in the treatment of hypertension, hyperlipidemia, diabetes mellitus, nephritis, asthma, arthritis, inflammatory bowel diseases and many other diseases. The certain mechanism of these effects is still unclear. So, G. lucidum is not suggested as a therapeutic agent. It is utilized mostly as an immune enhancer and a health supplement. In these paper, we report a case with acute pancreatitis presenting with different clinical findings.
\end{abstract}

Key words: Acute pancreatitis, ganoderma lucidum

Received / Geliş tarihi: 27.10.2016, Accepted / Kabul tarihi: 17.08.2017

${ }^{1}$ Izmir Bozyaka Training and Research Hospital, Internal Medicine Department, Izmir

${ }^{2}$ IzmirAtaturk Training and Research Hospital, Internal Medicine Department, Izmir

${ }^{3}$ Izmir Bozyaka Training and Research Hospital, Family Medicine Department, Izmir

*Address for Correspondence / Yazışma Adresi: Arif Yüksel, Izmir Bozyaka Training and Research Hospital, Internal Medicine Department, IzmirE-mail: ayuksel1968@ gmail.com

Yüksel A, Gezer E, Gümüş ZZ, Tuncer Ö. Ganoderma Lucidum Induced Acute Pancreatitis in The Elderly. TJFMPC, 2017;11(4): 288-291.

DOI:10.21763/tjfmpc.359861 


\section{INTRODUCTION}

Ganoderma lucidum (Lingzhi in Chinese and Reishi in Japanese) is a popular medicinal mushroom and has been used for about 2.000 years in Chinese medicine 1. Many possible mechanisms and bioactive constituents such as polysaccharides, some peptides, triterpenoids, nucleosides, fatty acids, ergosterols and many others forming this fungus have been considered to be responsible for the effects of . lucidum $^{2}$. G. lucidum has also been demonstrated that it can be used in the treatment of hypertension, hyperlipidemia, diabetes mellitus, nephritis, asthma, arthritis, inflammatory bowel diseases and many other diseases ${ }^{3}$.

Acute pancreatitis is an acute inflammatory process of the pancreas ${ }^{4}$. Many factors are known to induce this disorder; however, the number of cases diagnosed as "idiopathic" is still needs to get decreased. A number of conditions known to cause acute pancreatitis are listed in Table 1. To determine the etiology, all patients should have a detailed history, full physical examination, laboratory evaluation (serum amylase or lipase, triglyceride level, calcium level, and liver biochemistries), and abdominal ultrasound (repeated, if initially negative for gallstones). If they don't yield an etiology, a few more imaging techniques such as magnetic resonance cholangiopancreatography (MRCP) and endoscopic ultrasound (EUS) need to be performed. Among all described causes of acute pancreatitis, medicinal herbs are not mentioned and no known diagnostic test is available for this possible cause. Although many clinical researches on G. lucidum have been reported, knowledge about the side effects or intoxication due to this fungus has not been mentioned before in English language literature. Here, we presented a case who had acute pancreatitis after frequent use of G. lucidum.

\section{CASE}

A 69 year-old female patient admitted to emergency with upper abdominal pain, nausea and vomiting. She reported no alcohol consumption nor recently used medicine. On the physical examination, she had abdominal tenderness and distention with hypoactive bowel sounds. Initially biochemical tests including elevated levels of amylase and lipase, are listed in Table 2. Abdominal ultrasound revealed normal biliary tree and gall bladder. With these findings, she was diagnosed as non-alcoholic and non-biliary acute pancreatitis.

She was hospitalized and examined for the other reasons of pancreatitis. Laboratory tests showed normal calcium $(9.4 \mathrm{mg} / \mathrm{dL})$ and triglycerides (84 $\mathrm{mg} / \mathrm{dL}$ ) levels and no leukocytosis (WBC: 5.490/L). No sign for any infection was found. She also had no history for trauma. Her family history was normal. A magnetic resonance cholangiopancreatography scanning and an endoscopic ultrasound imaging revealed normal biliary tree, gall bladder and pancreatic duct anatomy.

We used Ranson's criteria (non-gallstone pancreatitis) for assessing prognosis in early acute pancreatitis and the score was 1. Right after beginning iv hydratation treatment and cessation of enteral feeding, the clinical findings disappeared. Therefore, there was no need for computed tomography. To eliminate autoimmune pancreatitis, serum IgG4 was studied and found normal. When the medical history of the patient was deepened, she reported that she had regularly drunk a kind of herbal tea including $0.5 \mathrm{gr} \mathrm{G}$. lucidum for the past one week to heal the pain of her knees. She drank 1 teaspoon of herbal tea per day for week. There is an averageof $0,5 \mathrm{gr}$ gonaderma lucidum in a teapot bag. Since no other reason was demonstrated, she was diagnosed as G. lucidum induced acute pancreatitis. After recovery, she was discharged with the recommendations not to use the same herbal tea again.

\section{DISCUSSION}

Ganoderma lucidum is known with remarkable health benefits in many disorder and diseases. $G$. lucidum is a Basidiomycetes fungus belonging to polypore family of mushrooms and possessing the therapeutically potent lanosteroidal skeleton, terpenoids are upheld for their invariable participation in therapeutically diverse bioacitivities 5,6 . There are some evidences claimed that $G$. lucidum increases glycogen synthesis and cholesterol homeostasis, decreases gluconeogenesis, TNF- $\alpha$ and other pro-inflammatory cytokines. $G$. lucidum can also inhibate pro-invasive gene replication ${ }^{7,8,9}$. Other than the diseases mentioned above, G. lucidum is also used to treat hepatopathy, chronic hepatitis, neurasthenia, insomnia, bronchitis, gastric ulcers, atherosclerosis, leukopenia, anorexia and cancer ${ }^{3}$.

Despite of the wide range benefits, there is no data about the side effects of the fungi. Pytochemical studies over the last 40 years led to the isolation of 431 secondary metabolites from various Ganoderma species. Secondary metabolites isolated from Ganoderma and their biological significance are unclear. In fact, there is a recent study revealing 


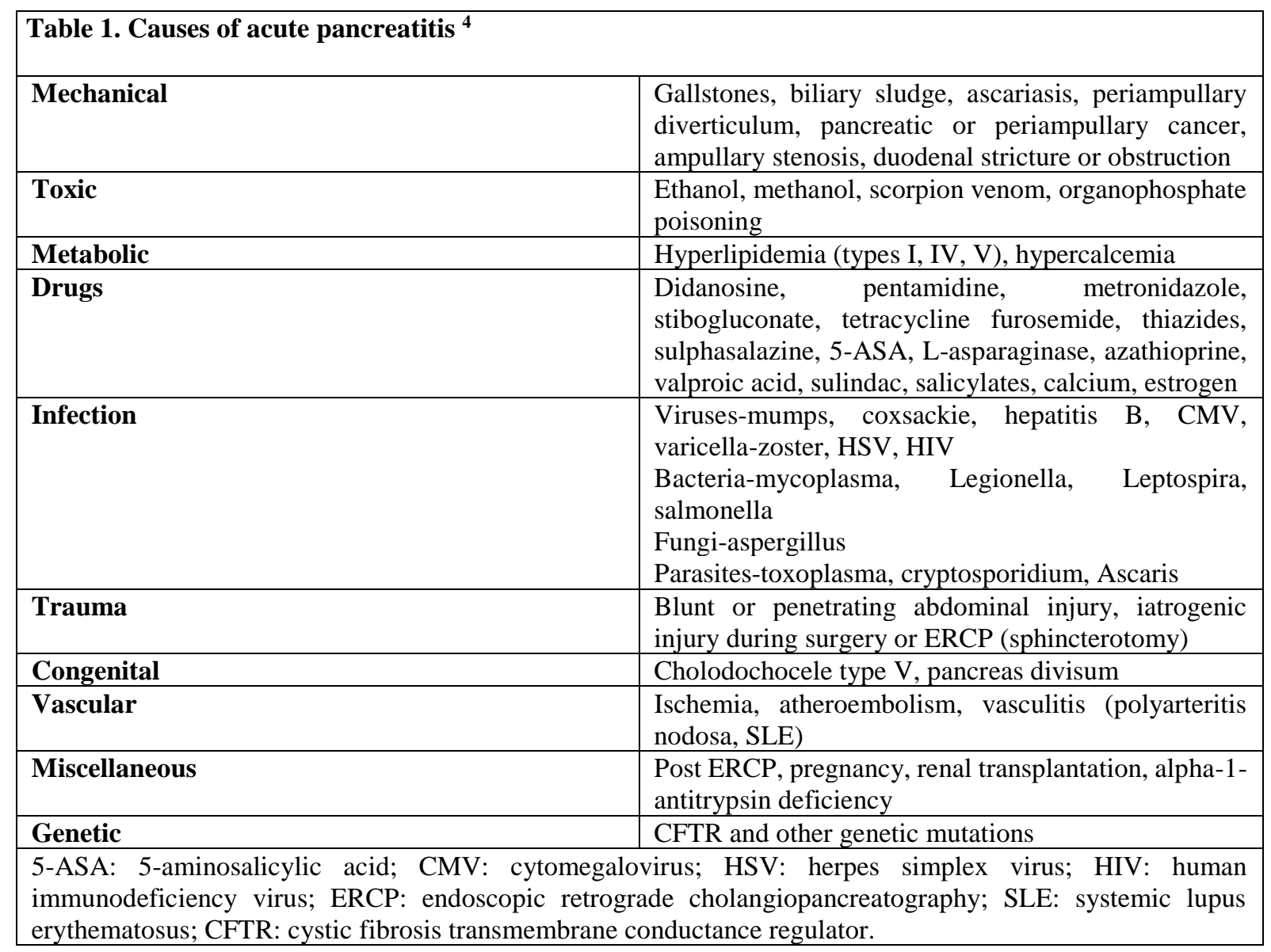

\begin{tabular}{|c|c|l|c|c|c|}
\hline \multicolumn{2}{|l|}{ Table 2. Initial laboratory parameters } & Lab results & Normal range \\
\hline & Lab results & Normal range & & 107 & $0-50$ \\
\hline P.Urea (mg/dL) & 20 & $17-43$ & AST (IU/L) & $0-50$ \\
\hline P.Creatinine(mg/dL) & 0.7 & $081-1.44$ & ALT (IU/L) & 77 & $0.3-1.2$ \\
\hline P.Albumin (g/dL) & 3.76 & $3.5-5.2$ & $\begin{array}{c}\text { T.Bilirubin } \\
(\mathbf{m g} / \mathbf{d L})\end{array}$ & 2.05 & $74-106$ \\
\hline T.cholesterol (mg/dL) & 168 & $0-200$ & $\begin{array}{c}\text { Blood Glucose } \\
(\mathbf{m g} / \mathbf{d L})\end{array}$ & 118 & $0-248$ \\
\hline TG (mg/dL) & 84 & $0-150$ & LDH (U/L) & 190 & $0-5$ \\
\hline HDL (mg/dL) & 44 & $40-60$ & CRP (mg/L) & 27 & $4000-10000$ \\
\hline LDL (mg/dL) & 116 & 89 & WBC & 5480 & $11-16$ \\
\hline P. CA (mg/dL) & 9.4 & $8.8-10.6$ & $\begin{array}{c}\text { Hemoglobin } \\
\text { (g/dL) }\end{array}$ & 13.3 & $37-54$ \\
\hline Amilase(U/L) & 3110 & $22-80$ & Hematocrit (\%) & 38 & \\
\hline Lipase (U/L) & 955 & $0-60$ & & & \\
\hline
\end{tabular}


attenuating effect of G. lucidum polysaccharides on diethyldithiocarbamate (DDC)-induced chronic pancreatitis $(\mathrm{CP})$ in mice ${ }^{10}$. Koukou $\mathrm{Li}$ et al found out that Polysaccharides of Ganoderma lucidum strain S3 (GLPS3) have antioxidative and immunomodulatory activities. The total sugar content of GLPS3 is consisted of three parts, named GLPS3-I, GLPS3-II and GLPS3-III. The antioxidative activity of GLPS3-II from cultured fungus in vitro was revealed higher than other two polysaccharides. The superoxide dismutase (SOD) and glutathione peroxidase (GSH-Px) in serum were increased and the malondialdehyde (MDA) levels were reversely decreased by GLPS3 treatment. In addition to this, interleukin-1beta (IL-1 $\beta$ ) and interferon-gamma (INF- $\gamma$ ) levels were decreased most by GLPS3-II.

\section{REFERENCES}

1. Benzie IFF, Wachtel-Galor S. Herbal Medicine: Biomolecular and Clinical Aspects.2011;9(2):1111.

2. Lin ZB. Cellular and Molecular Mechanisms of Immuno-modulation by Ganoderma lucidum. J Pharmacol Sci 2005;99: 144 - 153.

3. Batra P, Sharma AK, Khajuria R. Probing Lingzhi or Reishi medicinal mushroom Ganoderma lucidum (higher Basidiomycetes): a bitter mushroom with amazing health benefits. Int J Med Mushrooms. 2013;15(2):127-43.

4. Sarles H. Revised classification of pancreatitisMarseille 1984. Dig Dis Sci 1985; 30:573-4.

5. Wang F, Zhou Z, Ren X, Wang Y, Yang R, Luo J, Strappe P.Effect of Ganoderma lucidum spores intervention on glucose and lipid metabolism gene expression profiles in type 2 diabetic rats. Lipids Health Dis. 2015; May 22;14(1):49.

6. Gill BS, Sharma P, Kumar R, Kumar S. Misconstrued versatility of Ganoderma lucidum: a key player in multi-targeted cellular
In our case, no other reason but G. lucidum was found for the etiology of acute pancreatitis. Medical literature has no case reported, so far, on the side effects of this fungus. Since there are not sufficient clinical researches on the complications of G. lucidum, new studies are needed to understand the mechanism of acute pancreatitis due to G. lucidum. Related to this, the age of our patient which makes her belonged to geriatric population, may contribute the occurrence of $G$. lucidum based treatment's side effects; however, this mechanism and its effect on younger population is not known, yet. As we emphasize the importance of detailed anamnesis, we suggest considering that G. lucidum, a medicinal fungi with countless benefits, can cause negative complications.

signaling. Tumour Biol 2016 Mar;37(3):2789804.

7. Baby S, Johnson AJ, Govindan B. Secondary metabolites from Ganoderma. Phytochemistry. 2015 Jun;114(1):66-101.

8. Liu C, Dunkin D, Lai J, Song Y, Ceballos C, Benkov K, Li XM.Anti-inflammatory Effects of Ganoderma lucidum Triterpenoid in Human Crohn's Disease Associated with Downregulation of NF- $\kappa$ B Signaling. Inflamm Bowel Dis. 2015 Aug;21(8):1918-25.

9. Loganathan J, Jiang J, Smith A, Jedinak A, Thyagarajan-Sahu A, Sandusky GE, Nakshatri $\underline{\mathrm{H}}, \underline{\text { Sliva D. The mushroom Ganoderma }}$ lucidum suppresses breast-to-lung cancer metastasis through the inhibition of proinvasive genes .Int j Oncol. 2014 Jun;44(6):2009-15.

10. Koukou Lia, Min Yub, Yang Hua, Guangming Rena, Tingting Zanga, Xiuhong Xua, Juanjuan Qua. Three kinds of Ganoderma lucidum polysaccharides attenuate DDC-induced chronic pancreatitis in mice. ChemicoBiological Interactions. 2016 Mar 5;247:30-8. 